\title{
Effect of different factors on in vitro growth and shoot proliferation of guava (Psidium guajava L.) cv. Allahabad Safeda
}

\author{
Smita Kadam ${ }^{1}$, R. M. Patel ${ }^{1}$ and Pushpraj Singh ${ }^{2 *}$ \\ ${ }^{1}$ Department of Biotechnology, ASPEE College of Horticulture and Forestry, Navsari Agricultural University, \\ Navsari-396450 (Gujarat ), INDIA \\ ${ }^{2}$ International Crops Research Institute for the Semi-Arid Tropics , Patancheru, Hyderabad -502324 (Telangana), INDIA \\ *Corresponding author. E-mail: Pushprajsngh9@gmail.com
}

Received: February, 19, 2016; Revised received: August 4, 2016; Accepted: November 3, 2016

\begin{abstract}
In the present experiment an attempt has been made to optimize the effect of different medium, levels of sucrose, $\mathrm{pH}$, adenine sulphate and light intensity for culture establishment and shoot proliferation in guava using nodal segment explants. Culture establishment was greatly influenced by media types. Maximum establishment of explants (74.57\%) was recorded on MS medium supplemented with $2.0 \mathrm{mg} / \mathrm{l} \mathrm{BAP}+0.2 \mathrm{mg} / \mathrm{l} \mathrm{IBA}$. In proliferation study, the maximum shoot proliferation was observed in MS $+1 \mathrm{mg} / \mathrm{l} \mathrm{BAP}+0.25 \mathrm{mg} / \mathrm{G} \mathrm{GA}$. Sucrose $3 \%$ was found to be more favorable for maximum proliferation and growth of shoots moreover, it was reduced gradually as increased or decreased levels of sucrose from $30 \mathrm{~g} / \mathrm{l}$. among the various $\mathrm{pH}$ levels tested, $\mathrm{pH} 5.5$ recorded maximum number of shoots $(8.08)$ and maximum length of shoots $(3.75 \mathrm{~cm})$.In proliferation medium the length of shoot, numbers of shoots and growth rate were increased as increased the adenine sulphate level in the medium. Maximum proliferation was observed on $160 \mathrm{mg} / \mathrm{l}$ adenine sulphate in the medium. High light intensity 3000 lux was found to be most suitable for proper growth of regenerated shoots. Low light intensity (1000 lux) resulted in stunted growth. All the above factors significantly influenced shoot multiplication and growth. Thus, optimization of these factors showed significantly increased number of shoots and rapid multiplication. This could be useful for the in vitro production of cost effective healthy planting material of guava
\end{abstract}

Keywards: Adenine sulphate, Light intensity, Multiplication, $\mathrm{pH}$, Shoots

\section{INTRODUCTION}

Guava (Psidium guajava L.) comes under the family of Myrataceae, originated from tropical America and Peru. It is a major fruit crop of tropical, subtropical and arid region of the country. It is also known as a poor man's fruit. Guava fruits contain higher amount of vitamin $\mathrm{C}$ and also rich in iodine and calcium. Leaves and bark used to treat diarrhea and heal the wounds. Among the different cultivars of guava cv. Allahabad Safeda is most popular and delicious fruit. Traditionally, guava is propagated by seeds but due the natural cross pollination (Purseglove, 1968) there are substantial variability exhibits in the seedling plants (Pontikis, 1996). Hence, to overcome this problem, vegetative methods (budding, inarching, grafting, air layering etc.) are used to produce sapling for large scale plantation. However, these vegetative methods are tedious, time consuming and season dependent (Gautam et al., 2010) which is barrier to rapid and mass clonal propagation. Due to slow process of multiplication, availability of true to type planting material of newly released improved cultivars/better clones are often in short supply. Thus, clonal propagation is an urgent necessity for rapid multiplication of desirable clone. In vitro cloning as become a rapidly expanding reality nowadays that evident from the number of species being successfully propagated through this technique. This has emerged as a potential means of rapid vegetative propagation of plants which can go a long way in solving many problems in fruit crops. The major advantage offered by in vitro propagation technique in guava are increased rate of multiplication, disease free uniform propaguals, rapid selection and multiplication of elite genotypes and year round availability of planting materials. The technique of tissue culture in guava has been demonstrated earlier (Hari Prakash and Tiwari, 1996; Joshee, 2002; Singh et al., 2002; Ali et al., 2003; Meghawal et al., 2003; Rathore et al., 2004; Kumar et al., 2006; Mishra et al., 2007; Zamir et al., 2007; Shah et al., 2008 and Rai et al., 2008). Although, these studies are concentrated mostly on evaluation of specific media different plant growth regulators and explants types for in vitro plantlet production. Each tissue types have its own requirement of medium formulations and cultural conditions (Narayanswamy, 1996). Success of in vitro culture considerably depends upon the various physical factors such as quality and quantity of light, temperature, pho- 
toperiod, $\mathrm{pH}$ and concentration of carbohydrates. Addition of growth additives like adenine sulphate into medium enhances cell growth and increase shoot multiplication (Rajore et al., 2002; Kaur et al., 1998 and Al-Suliaman, 2010) .The experiment was designed in order to study all the factors like different media, sucrose, $\mathrm{pH}$, adenine sulphate and light intensity for culture establishment and shoot proliferation in guava from nodal segment explants.

\section{MATERIALS AND METHODS}

Explants preparation and surface sterilization: Nodal segments were collected from newly emerged shoots having at least 4-5 nodes from 10-15 year old mature guava tree cv. Allahabad Safeda. Shoots were defoliated and washed thoroughly in running tap water for 2 hours to remove traces of dirt. The shoots then cut into small pieces having 2-3 nodes each to facilitate sterilization process. They were kept in a solution of 0.05 per cent bavistin (carbendazim 50 per cent WP) and 0.01 per cent streptocyclin for two hours. Then they were treated with 10 per cent solution of Teepol for 10 minutes. All traces of detergent were removed by repeated washing in double distilled water. Further, sterilization procedures were carried out under aseptic conditions in laminar air flow cabinet. The surface sterilization was made using 0.1 per cent mercuric chloride solution for 5 minutes. Explants thoroughly rinsed at least three times with autoclaved de-ionized distilled water. Sterilized shoot segments were then cut and trimmed into small nodal segment explants of 1-2 $\mathrm{cm}$ length quickly inoculated on the nutrient medium.

Culture media and culture condition: The basal medium of MS, B5 and WPM was prepared from the concentrated stock solutions as described by (Murashige and Skoog, 1962; Gamborg, 1968 and Lloyd and McCown, 1980). Medium pH was adjusted to 5.7 by using $0.1 \mathrm{~N} \mathrm{NaOH}$ or $0.1 \mathrm{~N} \mathrm{HCl}$ prior to autoclave at $121^{\circ} \mathrm{C}$ and $15 \mathrm{Ib} / \mathrm{in} 2$ for $20 \mathrm{~min}$. Sugar was added at $30 \mathrm{gm} / 1$ and medium were solidified with $8 \%$ agar. Explants were inoculated in $250 \mathrm{ml}$ glass bottles filled with $30 \mathrm{ml}$ medium. Cultures were incubated in a culture room at $26+2^{\circ} \mathrm{C}$ temperature of with $55 \pm 5$ per cent relative humidity. Light in the culture room was provided using fluorescent tubes with 16:8 hours light/ dark cycle, kept $50 \mathrm{~cm}$ above bench surface at 3000 lux.

Standardized the media for culture establishment: Different media viz. MS, B5 and WPM were test to standardize the most suitable culture establishment medium for guava. Sterilized 2-3 cm nodal segments were inoculated into different media supplemented with $2.0 \mathrm{mg} / \mathrm{l} \mathrm{BAP}+0.2 \mathrm{mg} / \mathrm{l} \mathrm{IBA}$. Subculturing of explants was done at one week interval. Observations were recorded every 4-5 days interval. The best medium found in the trail was further used for shoot proliferation study.

Standardize the medium compositions for shoot proliferation: The trial on shoot proliferation was conducted in MS medium supplemented with different concentration of BAP $(1.0-2.0 \mathrm{mg} / \mathrm{L})$ in combination with IBA $(0.2 \mathrm{mg} / \mathrm{l}), \mathrm{GA}_{3}(0.25-50 \mathrm{mg} / \mathrm{l})$ and kinetin (0.1-0.2 mg/l). Small 1-2 cm nodal segments isolated from 5-6 weeks old in vitro established shoots were inoculated into medium as per the treatment combinations. Subculturing of explants was done at three weeks interval. The treatment respond well in shoot proliferation was further used to test the effect of different medium $\mathrm{pH}$ level, sucrose concentration, adenine sulphate and Light on in vitro shoot proliferation in guava.

Optimizing the factors affecting on shoot proliferation: In vitro proliferated 5-6 weeks old shoots were cut and separated into $1-2 \mathrm{~cm}$ explants for testing the influence of different medium $\mathrm{pH}$ levels, sucrose concentrations, adenine sulphate and Light intensity on in vitro shoot proliferation. Treatments were allocated in four different batches. MS medium $+1.0 \mathrm{mg} / \mathrm{l} \mathrm{BAP}+$ $0.25 \mathrm{mg} / \mathrm{l} \mathrm{GA}_{3}$ was used for entire trail. Five different levels $(1,2,3,4$, and $5 \%)$ of sucrose was tested in the first batch of culture, another batch was made of four level of Adenine sulphate $(20,40,80$, and $100 \mathrm{mg} / \mathrm{l})$. Effect of adenine sulphate was tested with $3.0 \%$ sucrose level in medium, whereas, the $\mathrm{pH}$ of medium was maintained at 5.7 for both the cultures. Influence of different $\mathrm{pH}$ levels (4.5, 5.0. 5.5, 5.7, 6.0 and 6.5) was tested in third batch of culture. Medium $\mathrm{pH}$ was adjusted prior to autoclaving. The effect of light intensity were tested by keeping the culture into three different (1000, 2000 and 3000 lux) light intensity, provided by white fluorescent tube of 36 watt, kept 50 $\mathrm{cm}$ above bench surface.

Statistical analysis: Experiments were setup in the completely randomized design and each treatment was repeated three times. Each treatment consisted of 20 explants in ten glass bottles with two explants in each. Means separation was done according to Least Significant Differences (LSD) at 5\% level (Pansey and Sukhatme 1985).

\section{RESULTS AND DISCUSSION}

Effect of different media on culture establishmen: Establishment of nodal explants was significantly influenced by the medium concentration in guava. Among the different (MS, B5 and WPM) media tested, Maximum establishment of explants $(74.57 \%)$ was recorded on MS medium supplemented with $2.0 \mathrm{mg} / \mathrm{l}$ $\mathrm{BAP}+0.2 \mathrm{mg} / \mathrm{l} \mathrm{IBA}$ followed by in B5 and WPM (Table 1).Higher number of shoots and internodes/ explants was notice in MS medium (Fig1). Moreover, minimum days for shoot initiation (9.36) were also observed in the same medium. Similarly, Siddiqui and Farooq (1997) was also recorded maximum culture establishment and shoot growth in guava in MS medium, compared to Blaydes, and WPM. Suitability of MS medium for culture establishment and shoot 
Smita Kadam et al. / J. Appl. \& Nat. Sci. 8 (4): 1999-2006 (2016)

Table 1. Effect of different media on establishment of explants of guava cv. Allahabad Safeda.

\begin{tabular}{lcccc}
\hline $\begin{array}{c}\text { Media } \\
\text { Composition }\end{array}$ & $\begin{array}{c}\text { Establishment } \\
(\boldsymbol{\%})\end{array}$ & $\begin{array}{c}\text { Days taken for estab- } \\
\text { lishment }\end{array}$ & $\begin{array}{c}\text { Length of Shoot } \\
(\mathbf{c m})\end{array}$ & $\begin{array}{c}\text { Number of inter- } \\
\text { nodes/ explant }\end{array}$ \\
\hline MS & $74.57(59.69)^{*}$ & 9.36 & 2.03 & 2.23 \\
B5 & $49.43(44.65)$ & 12.5 & 0.76 & 0.76 \\
WPM & $45.86(42.61)$ & 14.64 & 0.66 & 0.53 \\
S.Em. \pm & 0.25 & 0.16 & 0.03 & 0.03 \\
CD at 5\% & 0.73 & 0.47 & 0.09 & 0.14 \\
CV \% & 1.34 & 6.07 & 6.15 & 5.42 \\
\hline
\end{tabular}

*Figures in parentheses are arc sine transformed value

Table 2. Effect of different plant growth regulators on proliferation of culture of guava cv. Allahabad Safeda.

\begin{tabular}{|c|c|c|c|}
\hline Treatments & $\begin{array}{c}\text { Proliferation } \\
(\%)\end{array}$ & $\begin{array}{c}\begin{array}{c}\text { Length of shoot } \\
(\mathrm{cm})\end{array} \\
\end{array}$ & $\begin{array}{c}\begin{array}{l}\text { No. of internodes/ } \\
\text { shoot } \\
\text { (cm) }\end{array} \\
\end{array}$ \\
\hline BAP $2.0 \mathrm{mg} / \mathrm{l}+\mathrm{IBA} 0.20 \mathrm{mg} / \mathrm{l}+\mathrm{GA}_{3} 0.25 \mathrm{mg} / \mathrm{l}$ & $61.00(51.36)^{*}$ & 3.07 & 2.14 \\
\hline BAP $2.0 \mathrm{mg} / \mathrm{l}+\mathrm{IBA} 0.20 \mathrm{mg} / \mathrm{l}+\mathrm{GA}_{3} 0.50 \mathrm{mg} / \mathrm{l}$ & $57.00(49.02)$ & 2.71 & 2.51 \\
\hline BAP $1.0 \mathrm{mg} / \mathrm{l}+\mathrm{GA}_{3} 0.25 \mathrm{mg} / \mathrm{l}$ & $79.33(62.96)$ & 3.61 & 5.51 \\
\hline BAP $1.0 \mathrm{mg} / \mathrm{l}+\mathrm{GA}_{3} 0.50 \mathrm{mg} / \mathrm{l}$ & $71.00(57.42)$ & 3.11 & 3.51 \\
\hline BAP $2.0 \mathrm{mg} / \mathrm{l}+\mathrm{GA}_{3} 0.25 \mathrm{mg} / \mathrm{l}$ & $69.00(56.17)$ & 2.91 & 3.07 \\
\hline BAP $2.0 \mathrm{mg} / \mathrm{l}+\mathrm{GA}_{3} 0.50 \mathrm{mg} / \mathrm{l}$ & $57.00(49.02)$ & 2.80 & 2.52 \\
\hline BAP $2.0 \mathrm{mg} / \mathrm{l}+\mathrm{IBA} 0.20 \mathrm{mg} / \mathrm{l}+\mathrm{KIN} 0.10 \mathrm{mg} / \mathrm{l}$ & $52.33(46.34)$ & 2.51 & 2.21 \\
\hline BAP $2.0 \mathrm{mg} / \mathrm{l}+\mathrm{IBA} 0.20 \mathrm{mg} / \mathrm{l}+\mathrm{KIN} 0.20 \mathrm{mg} / \mathrm{l}$ & $55.00(47.87)$ & 2.11 & 2.51 \\
\hline BAP $1.0 \mathrm{mg} / \mathrm{l}+\mathrm{KIN} 0.10 \mathrm{mg} / \mathrm{l}$ & $62.33(52.14)$ & 2.21 & 3.07 \\
\hline BAP $1.0 \mathrm{mg} / \mathrm{l}+\mathrm{KIN} 0.20 \mathrm{mg} / \mathrm{l}$ & $73.66(59.12)$ & 3.07 & 4.09 \\
\hline BAP $2.0 \mathrm{mg} / \mathrm{l}+\mathrm{KIN} 0.10 \mathrm{mg} / \mathrm{l}$ & $66.99(54.93)$ & 2.07 & 2.51 \\
\hline BAP $2.0 \mathrm{mg} / \mathrm{l}+\mathrm{KIN} 0.20 \mathrm{mg} / \mathrm{l}$ & $62.33(52.14)$ & 2.10 & 2.71 \\
\hline S.Em. \pm & 0.09 & 0.03 & 0.03 \\
\hline $\mathrm{CD}$ at $5 \%$ & 0.26 & 0.09 & 0.08 \\
\hline $\mathrm{CV} \%$ & 0.98 & 5.83 & 4.84 \\
\hline
\end{tabular}

*Figures in parentheses are arc sine transformed value

Table 3. Effect of different level of sucrose on in vitro shoot proliferation of culture of guava cv. Allahabad Safeda.

\begin{tabular}{lccc}
\hline $\begin{array}{c}\text { Sucrose } \\
(\%)\end{array}$ & $\begin{array}{c}\text { Proliferation } \\
(\boldsymbol{\%})\end{array}$ & $\begin{array}{c}\text { No. of shoots } \\
\text { per culture }\end{array}$ & $\begin{array}{c}\text { Length of } \\
\text { shoot } \\
(\mathbf{c m})\end{array}$ \\
\hline 1 & $00.00(00.52)$ & 0.00 & 0.00 \\
2 & $43.29(41.13)$ & 2.26 & 1.30 \\
3 & $76.66(61.09)$ & 7.02 & 3.78 \\
4 & & 3.14 & 1.80 \\
5 & $53.33(46.89)$ & 1.10 & 1.16 \\
S.Em. \pm & $26.74(31.13)$ & 0.05 & 0.04 \\
C.D. at & 0.018 & 0.14 & 0.13 \\
5\% & 0.054 & 3.98 & 6.22 \\
C.V. \% & 0.11 & & \\
\hline
\end{tabular}

Figures in parentheses are arc sine transformed value.

growth in guava was reported by several other authors (Joshee, 2002; Singh et al., 2002; Ali et al., 2003; Rathore et al., 2004; Kumar et al., 2006; Mishra et al., 2007; Zamir et al., 2007 Shah et al., 2008; Rai et al., 2008 and Usman et al.,2012). Whereas, in contrast of our results, Meghawal et al., (2003) observed maximum explants establishment and shoot growth in WPM with the combination of $2.0 \mathrm{mg} / \mathrm{l} \mathrm{BAP}$. Similarly, Shekafandeh and Khosh-Khui (2008) achieved best results on both MS and WPM medium with 0.5-
Table 4. Effect of initial $\mathrm{pH}$ of the medium on in vitro shoot proliferation of culture of guava cv. Allahabad Safeda.

\begin{tabular}{lccc}
\hline $\begin{array}{c}\text { Media pH } \\
\text { Level }\end{array}$ & $\begin{array}{c}\text { Proliferation } \\
(\%)\end{array}$ & $\begin{array}{c}\text { No. of shoots } \\
\text { per explants }\end{array}$ & $\begin{array}{c}\text { Length of } \\
\text { shoot } \\
(\mathbf{c m})\end{array}$ \\
\hline 4.5 & $33.33(35.25)^{*}$ & 1.44 & 1.14 \\
5.0 & $53.41(46.94)$ & 2.48 & 1.70 \\
5.5 & $76.70(61.12)$ & 8.08 & 3.75 \\
5.7 & $73.46(58.97)$ & 7.02 & 3.50 \\
6.0 & $50.24(45.12)$ & 3.04 & 1.80 \\
6.5 & $00.00(0.52)$ & 0.00 & 0.00 \\
S.Em. \pm & 0.02 & 0.07 & 0.03 \\
C.D. at & 0.73 & & \\
5\% & 0.13 & 0.20 & 0.09 \\
C.V. $\%$ & & 4.18 & 3.45 \\
\hline
\end{tabular}

*Figures in parentheses are arc sine transformed value

$1.5 \mathrm{mg} / \mathrm{l} \mathrm{BA}$ in nodal segment explants of guava. Woody plant medium was found effective in some guava genotypes probably due to the lower concentration of major elements particularly nitrate salts. The variants in response of different media on culture establishment and shoot growth are could be due to the diverse physiological conditions of explants, their endogenous hormonal levels and the types and nutrients composition of media. (Yadav et al., 1990).

Effect of different growth regulators on shoot proliferation: Results on the response of different 
Table 5. Effect of adenine sulphate on in vitro shoot proliferation of culture of guava cv. Allahabad Safeda.

\begin{tabular}{|c|c|c|c|}
\hline $\begin{array}{c}\text { Adenine } \\
\text { sulphate } \\
\text { mg/l }\end{array}$ & $\begin{array}{c}\text { Proliferation } \\
(\%)\end{array}$ & $\begin{array}{l}\text { Cul- } \\
\text { ture } \\
\text { growth }\end{array}$ & $\begin{array}{c}\text { Length of } \\
\text { shoot } \\
\text { (cm) }\end{array}$ \\
\hline 40 & $\begin{array}{l}33.37 \\
(39.22)^{*}\end{array}$ & + & 1.28 \\
\hline 80 & $50.20(61.11)$ & ++ & 1.58 \\
\hline 120 & $66.70(58.90)$ & +++ & 2.22 \\
\hline 160 & $73.44(45.09)$ & ++++ & 3.62 \\
\hline S.Em. \pm & 0.02 & & 0.04 \\
\hline C.D. at $5 \%$ & 0.73 & & 0.11 \\
\hline C.V. \% & 0.13 & & 3.85 \\
\hline
\end{tabular}

*Figures in parentheses are arc sine transformed value. + Poor growth, ++ Good growth, +++ Very good growth, ++++ Excellent growth
Table 6. Effect of different light intensity on in vitro shoot proliferation of culture of guava cv. Allahabad Safeda.

\begin{tabular}{lccc}
\hline $\begin{array}{c}\text { Light inten- } \\
\text { sity } \\
(\mathbf{L u x})\end{array}$ & $\begin{array}{c}\text { Prolifera- } \\
\text { tion } \\
(\%)\end{array}$ & $\begin{array}{c}\text { No. of } \\
\text { shoots per } \\
\text { explants }\end{array}$ & $\begin{array}{c}\text { Length of } \\
\text { shoot } \\
(\mathbf{c m})\end{array}$ \\
1000 & $\begin{array}{c}46.70 \\
(46.09)^{*}\end{array}$ & 2.14 & 1.18 \\
2000 & 53.49 & 4.62 & 2.48 \\
& $(46.98)$ & & \\
3000 & 76.74 & 8.16 & 3.58 \\
& $(61.14)$ & & \\
S.Em. \pm & 0.02 & 0.05 & 0.04 \\
C.D. at 5\% & 0.07 & 0.14 & 0.12 \\
C.V. \% & 0.11 & 2.11 & 3.47 \\
\hline
\end{tabular}

*Figures in parentheses are arc sine transformed value

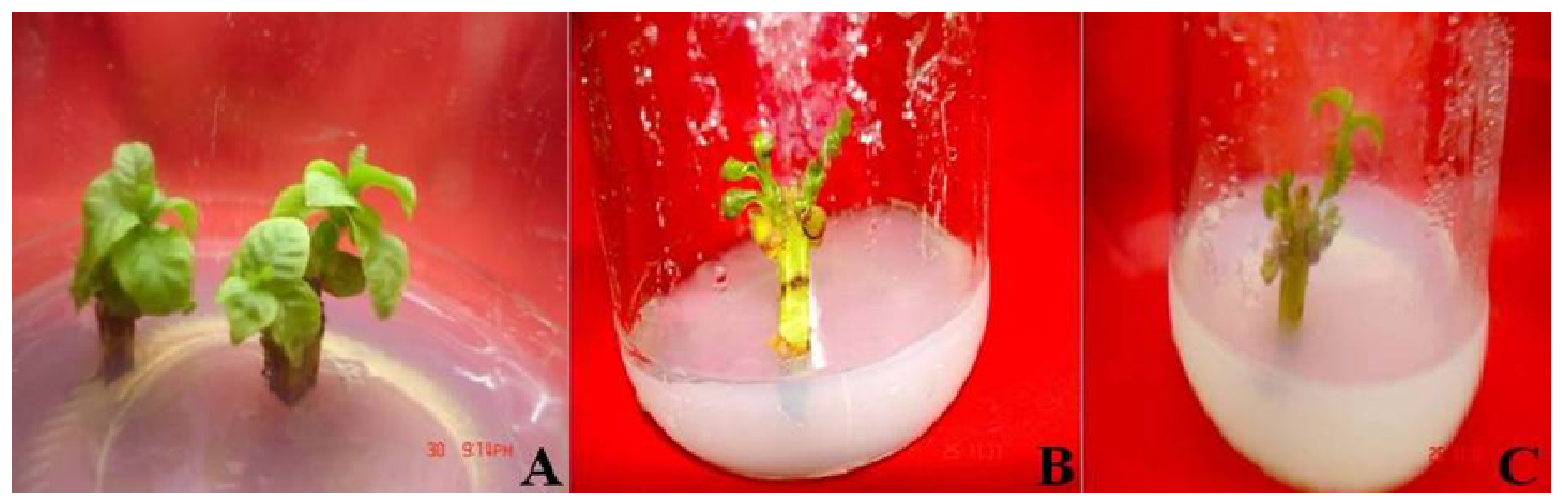

Fig. 1. (A) Establishment of nodal segment explants on MS medium (B) in WPM medium $(C)$ in B5 medium supplemented with $2.0 \mathrm{mg} B A P+0.2 \mathrm{mg} / \mathrm{IBA}$ after three weeks of inoculation.

levels of BAP, IBA, $\mathrm{GA}_{3}$ and Kinetin on shoot proliferation are illustrated in (Table 2). Maximum shoots proliferation per explant $(79.33 \%)$, length of shoots per explant $(3.61 \mathrm{~cm})$ and number of internodes per shoot (5.51) were recorded in the treatment MS medium + $1.0 \mathrm{mg} / \mathrm{l} \mathrm{BAP}+0.25 \mathrm{mg} / \mathrm{l} \mathrm{GA}$. followed by $1.0 \mathrm{mg} / \mathrm{l}$ $\mathrm{BAP}+0.20 \mathrm{mg} / \mathrm{l} \mathrm{KIN}$ and $1.0 \mathrm{mg} / \mathrm{l} \mathrm{BAP}+0.50 \mathrm{mg} / \mathrm{l}$ GA3 . Maximum proliferation of shoots with higher length was obtained on the lower concentration of BAP with $\mathrm{GA}_{3}$. Similar results were also obtained by (Rodriguez and Diaz Sala, 1991) in pear; (Mishra et al. 2007 and Shah et al. 2008) in guava. The role of cytokinins in shoot organogenesis is well established by Skoog and Miller (1957). In the present investigation cytokinins in combination with auxins was found less effective in shoot proliferation. However, it produced maximum numbers of proliferated shoots and highest length of shoot in combination with $\mathrm{GA}_{3}$ (Fig.2A) or Kin. (Fig.2B). these results are in line with (Loha and Rao, 1989 and Shah et al., 2008). This could be due to regeneration potential of cytokine which helped in shoot proliferation, and presence of $\mathrm{GA}_{3}$ in medium increased intermodal growth resulting increasing the length of shoots. Similarly, Hari Prakash and Tiwari
(1996) reported that the application of lower concentration of $\mathrm{GA}_{3}$ with $\mathrm{BA}$ was increased shoot length by increasing the intermodal length in guava.

Effect of levels of sucrose in medium on shoot proliferation: From the perusal of data given in (Table 3 ) is revel that the shoot proliferation was directly influence by the concentrations of sucrose in the medium. Maximum multiplication (76.66\%), number of shoot per explant (7.02) and maximum length of shoot $(3.78 \mathrm{~cm})$ was observed in $3 \%$ sucrose level (Fig. 2C). Moreover, the growth of shoot was declined gradually with increasing or decreasing levels of sucrose in the medium. Sharp declined in shoot growth was also observed by (Usman et al., 2012) with increasing the level of $60 \mathrm{~g} / \mathrm{l}$ sucrose into medium. Carbohydrate is an important element for plant growth, which affects osmotic regulation and photosynthetic activity in plants (Gibson, 2000). Numerous carbon energy sources are used for in vitro production in many species. Sucrose is the most widely accepted carbon energy source used in most of the in vitro studies (Jain and Babbar, 2003). It is a main and essential part of phloem sap in plants (Ahmad et al., 2007) and has potential to regulate physiological activity and cell differentiation in plants. 

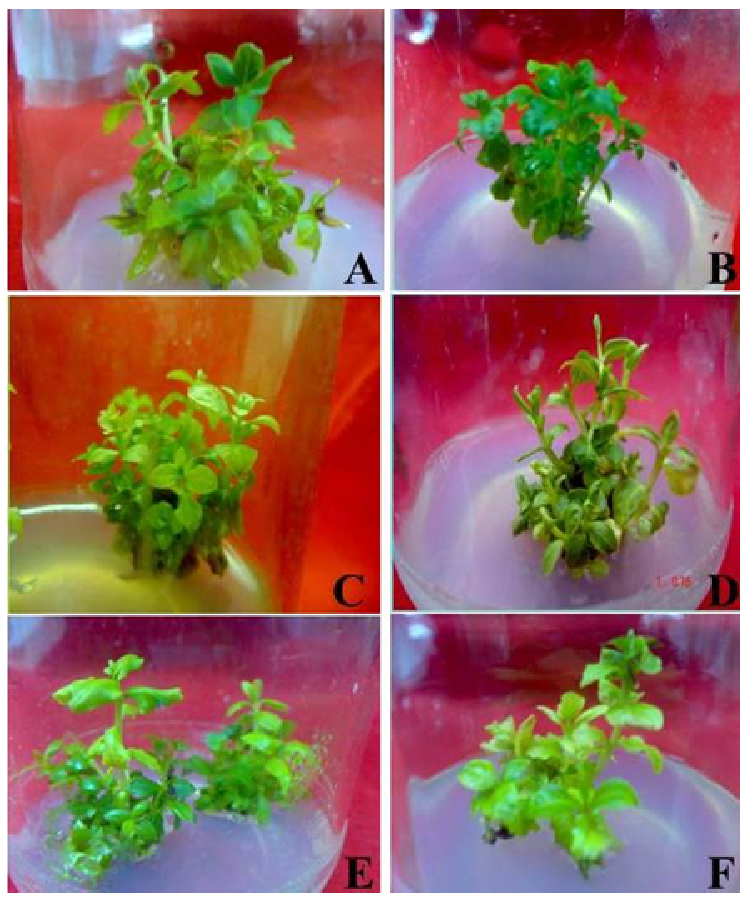

Fig. 2. (A) Shoot proliferation on $M S$ medium $+1.0 \mathrm{mg} / \mathrm{l}$

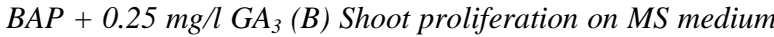
$1.0 \mathrm{mg} / \mathrm{l} \mathrm{BAP}+0.20 \mathrm{mg} / \mathrm{l} \mathrm{KIN}(C)$ Shoot proliferation in $3 \%$ sucrose on $\mathrm{MS}$ medium $+1.0 \mathrm{mg} / \mathrm{l} B A P+0.25 \mathrm{mg} / \mathrm{l} \mathrm{GA} A_{3 .}(D)$ proliferated shoots in $M S$ medium $+1.0 \mathrm{mg} / \mathrm{BAP}+0.25$ $\mathrm{mg} / \mathrm{l} \mathrm{GA}_{3}$ at $5.5 \mathrm{pH}(\mathrm{E}) 160 \mathrm{mg} / \mathrm{l}$ adenine sulphate in $\mathrm{MS}$ medium $+1.0 \mathrm{mg} / \mathrm{l} B A P+0.25 \mathrm{mg} / \mathrm{GA} \cdot(\mathrm{F})$ proliferated shoot at 3000 lux light intensity after three weeks of inoculation.

However, types and concentration is varying with plants and species (Yaseen et al., 2013). Photosynthetic activity of in vitro produced shoots is low (Praveena and Veeresham, 2014) and thus, maintaining an optimum level of sucrose in necessary for increasing shoot growth. In present study the growth was significantly influenced by different concentration of sucrose. Sucrose level 3 per cent in the medium was found optimum for better shoot proliferation. Several authors have reported the importance of the variability in concentration of a particular source of carbohydrates for getting desired response in shoot proliferation in different crops (Gurel and Gulsen, 1998) in Almond, (Asha and Nair, 2010) in Dioscorea pentaphylla, (Gabryszewska, 2011) in Syringa vulgaris L., (Anchalee, 2012) in Curcuma longa L. and (Gauchan, 2012) in Maize. Kumar and Kumar, (1998) reported that the 2 to $3 \%$ sucrose level is optimal for majority of crops for in vitro shoot growth. In our study optimum response in guava was obtained at 3 per cent sucrose level. However, in contrast of our finding (Usman et al., 2012) obtained the highest number shoots at $45 \mathrm{~g} / \mathrm{l}$ of sucrose in nodal segment explant of guava. Similarly, increasing sucrose level in medium was also produced higher shoot growth in apple rootstock (Yaseen et al., 2009) these variant responses could be explained by the different roles played by sugars in plant metabolism. Similar findings were also reported by (Patel, 2008) in papaya and (Shinde, 2008) in grape.

Effect of pH on shoot proliferation: The results on the influence of medium $\mathrm{pH}$ on shoot growth and proliferation are presented in (Table 3 ). Among the different $\mathrm{pH}$ levels $(4.5,5.0,5.5,5.7,6.0$ and 6.5), maximum shoot growth $(76.70 \%)$, length of shoot $(3.75$ $\mathrm{cm}$ ) and shoots per explants (8.08) was recorded on $\mathrm{pH}$ level 5.5 (Fig.2D) Followed by in the pH level 5.7. The trends in number of shoots per explants and length of longest shoot increased as $\mathrm{pH}$ level increased up to 5.5, then, subsequently shoot growth was declined. Importance of $\mathrm{pH}$ in tissue culture studies was reported earlier by (Gauthert, 1947) who observed drift in $\mathrm{pH}$ during the growth of a culture. Majority of fruit crops can grow satisfactory at pH level 5.6 to 5.8 (Conger, 1987 and Skirvin, 1981). In the present study, shoot proliferation and growth of guava was significantly influenced by $\mathrm{pH}$ level in medium. Influence of medium $\mathrm{pH}$ on shoot growth was reported by several authors in different plant species (Reeves et al., 1983) in peach, (Andersone and Levinsh, 2008) in Pinus sylvestris. (De Klerk et al., 2008) in apple and (Shekafandeh, 2010) in almond. The ambient $\mathrm{pH}$ could be desired for absorption of various nitrogen sources (Street, 1966). Variant medium $\mathrm{pH}$ probably decreases the absorption of nitrogen sources and sucrose uptake by the plants (Bhatia and Ashwath, 2005) which reduced cell differentiation and growth of plants. From the current results it revealed that the higher $\mathrm{pH}$ levels $(>5.7)$ as well as lower $(<5.5)$ were significantly affecting the shoot growth in vitro. The results are coincides with (Walli, 1996) in guava. However, Rai et al., (2008) recorded maximum shoot multiplication at $5.8 \mathrm{pH}$ from in vitro raised nodal segment of guava. Declining in shoot growth with increasing and decreasing $\mathrm{pH}$ levels might be due the well known effect of $\mathrm{pH}$ on the availability of nutrients from the medium (Wallihan et al., 1997 and Hurley et al., 1981).

Effect of adenine sulphate on shoot proliferation: It is evident from the (Table 4) that proliferation and growth of shoots were influenced by adenine sulphate. Maximum shoot proliferation $(73.44 \%)$ with the highest length $(3.62 \mathrm{~cm})$ was obtained at high concentration $160 \mathrm{mg} / \mathrm{l}$ adenine sulphate in MS medium +1.0 $\mathrm{mg} / \mathrm{l} \mathrm{BAP}+0.25 \mathrm{mg} / \mathrm{l} \mathrm{GA}_{3}$ (Fig. 2E). Whereas, lowest concentration of adenine sulphate $(40-80 \mathrm{mg} / \mathrm{l})$ was less effective in shoot proliferation. In general, effect of adenine sulphate was seen positive correlation in shoot growth. The results are accordance with Reuveni et al. (2004) and Patel (2008) in papaya. Effectiveness of adenine sulpahte in shoot growth and multiplication was reported by several workers in many plant species (Agnihotri et al., 2004) in papaya (Nandagopal and Kumara, 2006) in Cichorium intybus, (Srivastava and Benergee, 2008) in jatropa carcus, (Husain and Anis, 
2009) in Melia azedarach; (Zibbu and Batra, 2010) in Thavetia peruviana, (Gabriela, 2011) in white clover and (Singh et al., 2014) in pomegranate. In the present study adenine sulphate shown synergetic effect in culture growth with low level of cytokinin. Further, shoot proliferation was increased as the adenine sulphate increases into medium from $40 \mathrm{mg} /$ to $160 \mathrm{mg} / \mathrm{l}$. However, adenine sulphate $160 \mathrm{mg} / \mathrm{l}$ was found optimum for maximum soot proliferation. This could be due to the potentiality of the adenine sulphate to induced cell growth (Murashige, 1974) resulting increased the number of shoots and accelerated shoot proliferation. Proliferation and shoot growth is controlled by growth regulating substances present in the medium (Imran et al., 2012). Similar results were reported by (Siwach and Gill, 2011) in Ficus religiosa L. However, Thakur and Kanwar (2008) reported that the adenine sulphate was ineffective on shoot growth from shoot tip and nodal segment explants of pear.

Effect of light intensities on shoot proliferation: Among the different (1000, 2000 and 3000 lux) light intensity examined, the maximum shoot proliferation (76.74\%), with maximum number of shoots (8.16) and length of shoot $(3.58 \mathrm{~cm})$ was obtained at $3000 \mathrm{lux}$ light intensity, while, at 1000 lux light intensity registered minimum shoot proliferation with small length of shoots (Table 6). The increased proliferation of shoot, number of shoots and length of shoots were observed apparently as increased the light intensity (Fig 2F). Light is the most critical external factor that influences in vitro shoot growth and development of plantlets (Gupta and Jatothu, 2013). It is needed to regulate morphogenetic processes, such as initiation of roots, formation of shoots, chlorophyll and asexual embryogenesis, but low light intensity (300-1000 lux) is required to maintain the growth of callus tissue and early organogenesis (Sadhu, 1989). However, higher and lower level of light intensity causes adverse affect on shoot growth by reducing the photosynthesis rates (Gago et al., 2014). Light intensity for in vitro shoot growth varies with different crops and species (Chawla, 2002). In present study, 3000 lux light intensity was found optimum for maximum in vitro shoot multiplication and growth of guava. Proliferation of shoot was increased as increased the light intensity from 1000 to 3000 lux. The results are in line with (Kumar et al., 2006; Mishra et al., 2007 and Rai et al., 2008). Although, in contrast to our results (Zamir et al., 2007) found better shoot proliferation at 1500 lux light intensity in guava. Similarly, (Usman et al., 2012) reported maximum in vitro shoot proliferation at 2500 lux light intensity in cotyledonry explants of guava.

\section{Conclusion}

The present study has clearly demonstrated the potentiality of different factors for rapid clonal propagation. The main aim of in vitro propagation is to produce maximum numbers of true to type plantlets in shorter period of time at low cast. The optimized level of sucrose (3\%), pH level (5.5) and Light intensity (3000 lux) may be utilized further for in vitro rapid mass multiplication of guava cv. Allahabad Safeda.

\section{ACKNOWLEDGEMENTS}

Author Miss Smita Kadam is thankful to Department of Biotechnology and Dean, ASPEE College of Horticulture and Forestry, Navsari Agricultural University, Navsari, Gujarat for providing lab facilities and fulfilled necessities to carry out the M.Sc. thesis research.

\section{REFERENCES}

Ahmad, T., Abbasi, N.A., Hafiz, I.A. and Ali, A. (2007). Comparison of sucrose and sorbitol as main carbon energy source in morphogenesis of peach rootstock GF677. Pakistan Journal Botany, 39(4): 1264- 1275

Agnihotri, S., Singh, S.K., Jain, M., Sharma, M., Sharma, A.K. and Chaturvedi, H.C. (2004). In vitro cloning of female and male Carica papaya through tips of shoots and inflorescences. Indian J. Biotechnology, 3: 235-240

Ali, N.M., Mulwa, R.M.S., Notron, M.A. and Skirvin R.M. (2003). Micropropagation of guava (Psidium guajava). J. Hort. Sci. Biotechnol., 78 (5): 739 -741

Al-Sulaiman, M.A. and Barakat, M.N. (2010). In vitro shoot multiplication of Ziziphus spina-christi by shoot tip culture. African Journal of Biotechnology, 9 (6), 850857

Anchalee J. (2012). Effects of NAA BA and sucrose on shoot induction and rapid micropropagation by trimming shoot of Curcuma Longa L. International Transaction Journal of Engineering, Management, \& Applied Sciences \& Technologies, 17 (4):54-60

Andersone, U. and Levinsh, G. (2008). Medium pH affects regeneration capacity and oxidative enzyme activity of Pinus sylvestris in tissue culture. Acta Universitatis Latviensis, 745: 25-35

Asha, K.I. and Nair, G.M. (2010). Effect of different levels of sucrose and additives on In vitro Multiplication in Dioscorea pentaphylla L. Journal of Root Crops, 36 (1):33-38

Bhatia, P. and Ashwath, N. (2005). Effect of medium pH on shoot regeneration from the cotyledonary explants of tomato. Biotechnology, 4: 7-10

Conger, B.V. (1987). Cloning agricultural plants viz. in vitro techniques CRC pres. Florida, pp. 31-39

Chawla, H.S. (2002). Introduction to plant biotechnology, 2nd edn. Science Publishers, Inc, Enfield, New Delhi, pp. 43

DE Klerk, G.J., Hanecakova, J. and Jasik, J. (2008). Effect of medium- $\mathrm{pH}$ and MES on adventitious root formation from stem discs of apple. Plant Cell Tiss. Org. Cult., 95: 285-292

Gabriela, V. (2011). Effect on adenine sulphate on the in vitro evolution of white clover variety Trifolium repens L. Annals of University of Oradea, Fascicle Environmental Protection, XVI: 203-210

Gabryszewska, E. (2011). Effect of various levels of sucrose, nitrogen salts and temperature on the growth and development of Syringa vulgaris L. shoots in vitro. J. Fruit Ornam. Plant Res., 19 (2): 133-148 
Gago, J., Nuriez, L M., Landin, M., Flexas, J. and Gallego, P.P. (2014). Modeling the effects of light and sucrose on In Vitro propagated plants: A Multiscale System Analysis Using Artificial Intelligence Technology. PLOS ONE, 9 (1) : e85989

Gamborg, O.L. (1968). Nutrient requirements of suspension cultures of Soybean root cultures. Experimental Cell Research, 50: 151-158

Gauchan, D.P. (2012). Effect of different sugars on shoot regeneration of maize (Zea mays L.). Kathmandu University J. Sci. Eng. Technol., 8 (I):119-124

Gauthert, R.J. (1947). Sur la possibilite de realisem la culture indifinie des tissues de tubercules de carotte. C. R. Academic Science Paris, 208: 118-120

Gautam, N.N., Singh, K., Singh, B., Seal, S., Goel, A. and Goel, V.L. (2010). Studies on clonal multiplication of Guava (Psidium guajava L.) through cutting under controlled conditions. Australian J. Crop Science, 4 (9): 666-669

Gibson, S.I. (2000). Plant sugar response pathways. Part of a complex regulatory web. Plant Physiology, 124: 15321539

Gupta, S.D. and Jatothu, B. (2013). Fundamentals and applications of light-emitting diodes (LEDs) in in vitro plant growth and morphogenesis. Plant Biotechnology Reports, 7 (3): 211-220

Gurel, S. and Gulsen, Y. (1998). The Effects of different sucrose, agar and $\mathrm{pH}$ Levels on In vitro shoot production of Almond (Amygdalus communis L.) Turkish J. Botany, 22: 363-373

Hari Prakash, H. and Tiwar, J.P. (1996). Micropropagation of guava (Psidium guajava L.). J. Applied Horticulture, 2(1): $98-101$.

Hurley, N.K., Einert, A.E. and Hileman, L.E. (1981). Effect of $\mathrm{pH}$ on growth and quality of Iris Germanic L. HortScience, 16(5): 672-673

Husain, M.K. and Anis, M. (2009). Rapid in vitro multiplication of Melia azedarach L. (a multipurpose woody tree). Acta physiol. Plant., 31 (4):765-772

Imran, M.A., Begum, G., Sujatha, K. and Mallaiah, B. (2012). Effect of adenine sulphate (ads) with cytokinins on multiple shoot production in Carissa carandas (L.). International Journal of Pharma and Bio Sciences, 3 (1): 473-480

Jain, N. and Babbar, S.B. (2003). Effect of carbon source on the shoot proliferation potential of epicotyls explants of Syzygium cuminii. Biologia Plantarum, 47: 133-136

Joshee, N., Mutua, M., Yadav, A.K. and Zee, F. (2002). In vitro shoot bud induction and plant regeneration in guava as influenced by genotype. Acta Hort., 635: 279-285

Kaur, K., Verma, B. and Kant, U. (1998). Plants obtained from the Khair tree (Acacia catechu Willd.) using mature nodal segments. Plant Cell Rep., 17: 427-429

Kumar, A. and Kumar, V.A. (1998). Clonal tissue culture of important fruit crops. International book distribution co., pp. 35

Kumar, R., Tiwari, J.P. and Misra, K.K. (2006). In vitro cloning of chinease guava (Psidium friedrichsthalianum) (Berg) Nierdz. Progressive. Horticulture, 38 (1): 15 -21

Lloyd, G. and McCown, B. (1980). Commercially-feasible micropropagation of mountain laurel, Kalmia latifolia, by use of shoot-tip culture. Proc. Intern. Plant Prop. Soc., 30:421-426
Loha, C.S. and Rao, A.N. (1989). Clonal propagation of guava (Psidium guajava L.) from seedlings and grafted plants and adventitious shoot formation in vitro. Scientia Hort., 39: 31-39

Meghawal, P.R.; Singh, S.K. and Sharma, H.C. (2003). Micropropagation of Aneuploid guava. Indian J. Hort., 60 (1): $29-33$

Mishra, D.S., Tiwari, J.P. and Lal, S. (2007). In vitro cloning of guava (Psidium guajava L.) cv. Pant Prabhat. (ed. Proceeding of first international Symposium on Guava), Acta Horticulture, 735: 127-132

Murashige, T. (1974). Plant propagation through tissue culture. Annual Review of Plant Physiology, 5: 135-136

Murashige, T. and Skoog, F. (1962). A revised medium for rapied growth and bioassays with tobacco tissue cultures. Physiol. Plant., 15: 473-497

Nandagopal, S. and Ranjitha Kumari, B.D. (2006). Adenine sulphate induced high frequency shoot organogenesis in callus and in vitro flowering of Cichorium intybus L. cv. Focus - a potent medicinal plant. Acta Agriculture Slovenica, 87 (2): 415 - 425

Narayanswamy, S (1996). Regeneration of plant from tissue culture pp 182. In. Biotechnology in agriculture and forestry, Vol 35 tree IV (eds.Y.P.S Bajaj), Springer Verlag Berlin

Panse, V.G. and Sukhatme, P.V. (1985). Statistical methods for agricultural workes. Ed., ICAR, New Delhi

Patel, J. R. (2008). Micropropagation in papaya cv. Red Lady. M. Sc. thesis submitted to the Navsari Agricultural University, Navsari, Gujarat.

Pontikis, C.A (1996). Biotechnology in agriculture and forestry, pp.312. In. Biotechnology in agriculture and forestry, Vol 35 tree IV (eds.Y.P.S Bajaj), Springer Verlag Berlin.

Pravareena, C and Veeresham, C. (2014). Multiple shoot regeneration and effect of sugars on growth and nitidine accumulation in shoot culture of Toddalia asiatica. Pharmacognocy Magazine, 10 (3):480-486.

Purseglove, J. W. (1968). Tropical crops - Dicotyledone, Longman, Londan

Rajore, S., Sardana, J. and Batra, A. (2002). In vitro cloning of Jatropha curcas L. J. Plant Biol., 29 (2): 195-198.

Rai, M. K., Jaiswal, V. S. and Jaiswal, U. (2008). Effect of ABA and sucrose on germination of encapsulated somatic embryos of guava (Psidium guajava L.). Scientia Hort., 117: 302-305

Rathore, V., Shekhawat, N. S., Singh, R. P., Rathore, J. S. and Dagla, H. R. (2004). Cloning of adult trees of jamun (Sizygium cuminii). Indian J. Biotechnol., 3: 241245

Reeves, D.W., Horton, B.D. and Couvillon, G.A (1983). Effect of media and media ph on in vitro propagation of 'Nemaguard' peach rootstock. Scientia Hort., 21: 353-357

Reuveni, O., Shlesinger, D.R. and Lavi, U. (2004). In vitro clonal propagation of dioecious Carica papaya. Plant Cell Tiss. Org. Cult., 20(1): 41-46

Rodriguez, R. and Diaz Sala, C. (1991). Pear in vitro propagation using double phase culture system. Sci. Hort., 3: 62-64

Sadhu, M. K. (1989). Plant propagation. New Age International (P) Ltd. New Delhi. Pp 233

Shah, S. T., Zamir R., Ahmad, R., Ali, H. and Lutfullah, G. (2008). In vitro regeneration of plantlets from seedlings 
explants of guava (Psidium guajava 1.) cv. Safeda. Pak. J. Biotechnol., 40(3): 1195-1200.

Shekafandeh, A. Khosh-Khui, M. (2008). Effects of Bud Position and Culture Medium on Shoot Proliferation from Nodal Culture of Two Mature Guava Cultivars. Asian Journal of Plant Sciences, 7: 177-182.

Shekafandeh, A. (2010). The Effects of Ph Levels and Plant Growth Regulators on in vitro Regeneration of Almond (Prunus dulcis Mill.) World Applied Sciences Journal, 8 (11): 1322-1326.

Shinde, K. A. (2008). Micropropagation in grape cv. Thompson seedless. Unpublished M.Sc. (Hort.) thesis submitted to Navsari Agricultural University Navsari Gujarat. p. 72 .

Shrivastava, S. and Banerjee, M. (2008). In vitro clonal propagation of physic nut (Jatropha curcas L): influence of additives. Int. J. Integr. Biol., 3 (1):73-77.

Siddiqui, Z. M. and Farooq, S. A. (1997). Tissue culture studies on the nodal explants of guava. Indian J. Hort., 54 (4): $276-27$.

Singh, S. K., Meghawal, P. R., Sharma, H. C. and Sing S. P. (2002). Direct shoot organogenesis on hypocotyls explants from in vitro germinated seedlings of (Psidium guajava L.) cv. Allahabad Safeda. Scientia Hort., 95: 213-221.

Singh, P. and Patel, R.M. (2014). Factors influencing in vitro growth and shoot multiplication of pomegranate. The Bioscan, 9 (3): 1031-1035.

Siwach, P. and Gill, A.R. (2011). Enhanced shoot multiplication in Ficus religiosa L. in the presence of adenine sulphate, glutamine and phloroglucinol. Physiol. Mol. Bio. Plants, 17 (3): 271-280.

Skirvin, R.M. (1981). Fruit crops. Cloning Agricultural Plants via In vitro Techniques. CRC Press, Inc., Boca Raton, Florida. pp. 51-139.

Skoog, F. and Miller, C.O. (1957). Chemical regulation of growth and organ formation in plant tissue cultures in vitro. Symposia of the. Society of Experimental Biology
11: $118-131$.

Street, H. E. (1966). The nutrition and metabolism of plant tissue and organ culture. In Cells and Tissues in culture : Methods Biology and physiology (E. N. Willmer Ed.) vol. 3 Academic Press, London pp. 533-629.

Thakur, A. and Kanwar, J.S. (2008). Studies on in vitro shoot proliferation in pear. Indian J. Hort. 65 (4): 481-485.

Usman, M., Butt, M. and Bilquees, F. (2012). Enhanced in vitro multiple shoot induction in elite Pakistani guava cultivars for efficient clonal plant multiplication. African Journal of Biotechnology, 11 (44): 10182-19187.

Walli, V. K. (1996). In vitro propagation studies on guava (Psidium guajava L.). Ph. D. thesis submitted to Gujrat Agricuture University.

Wallihan, E. F., Sharpless, R. G. and Printy, W. L. (1997). Effect of $\mathrm{pH}$ on yield and leaf composition of Hydroponic Tomatoes. HortScience, 12 (4): 316-317.

Yadav, U., Lal, M. and Jaiswal, V. S. (1990). In vitro micropropagation of tropical fruit tree Syzygium cumini L. Plant Cell Tiss. Org. Cult., 21: 87-92.

Yaseen, M., Ahmad, M. T., Abbasi, N. A. and Hafiz, I. A. (2009). In vitro shoot proliferation competence of apple rootstocks M9 and M26 on different carbon sources. Pak. J. Biotechnol., 41: 1781-1795.

Yaseen, M, Ahmad, T., Sablok, G., Standardi, A., Ahmad Hafiz, I. (2013). Role of carbon sources for in vitro plant growth and development. Molicular Biology Reports, 40:2837-2849.

Zamir, R., Ali, N., Shah, S., Muhammad, T. and Shah, S. A. (2007). In vitro regeneration of guava (Psidium guajava L.) from shoot tips of mature trees. Pak. J. Bot. 39 (7): 2395-2398

Zibbu, G. and Batra, A. (2010). Effect of adenine sulphate on organogenesis via leaf culture in an ornamental plant: Thevetia Peruviana (PERS.) SCHUM. International Journal of Pharma and Bio Sciences, 1(2) 1-9. 